\title{
Development of Learning Methods Midwifery Emergency Clinical Skills
}

\author{
Lusiana El Sinta Bustami ${ }^{1}$, Laila Rahmi ${ }^{2}$, Fitrayeni $^{3}$, Feni Andriani ${ }^{4}$ \\ \{lusianaelsinta@yahoo.co.id ${ }^{1}$, lailarahmi8708@gmail.com², fitrayeni10@gmail.com³, \\ fenie_mcb89@yahoo.com ${ }^{4}$ \} \\ ${ }^{1-4}$ Midwifery Program, Faculty of Medicine, Universitas Andalas Padang, Indonesia
}

\begin{abstract}
Students who take Midwifery Emergency Clinical Skills Course will have the opportunity to have skills in mastering some aspects of competencies needed in management related to obstetric emergencies. This research combines qualitative and quantitative research. The results of the study showed that there were mean differences between student learning outcomes in the Midwifery Emergency Clinical Skills course in the class 2015 and class 2016 with $\rho$ value $=0.001$. Qualitatively, data / information has been obtained from students that provide an overview of students' responses to the action of developing learning methods which has been done. Development of learning methods can fell up the learning outcomes of graduates by uniforming the abilities / competencies possessed by clinical instructors and students.
\end{abstract}

Keywords: Learning Methods, Midwifery Emergency Clinical Skills

\section{Introduction}

\section{Position of Subjects in Curriculum Structure}

Midwifery Emergency Clinical Skills Subjects are one of the subjects that should be studied by semester VI students in Undergraduate Midwifery Program of Faculty of Medicine, Andalas University. Students who take lessons in this course will have the opportunity to have skills in mastering some aspects of the competencies needed to become a midwife in the management of midwifery emergencies. By mastering these skills students are expected to be able to perform Health Management and Midwifery Management maximally in community.

\begin{abstract}
Short Course Description
Midwifery Emergency Clinical Skills Subjects are one of the subjects that should be studied by semester VI students in the Midwifery Study Program of the Faculty of Medicine, Andalas University. Learning in Midwifery Emergency Clinical Skills Subjects has been prepared for 6 weeks in clinical skills laboratory which is adjusted to the implementation time of Block 6B. In the implementation of clinical skills guidance and training conducted in the laboratory for 6 weeks, the clinical skills supervisor (instructor) also conducts an evaluation of the guidance and training that has been done. Timing of assessment is handed over technically to each clinical skills instructor (the assessment is carried out per skill at the time of each completion of guidance on one skill competency, or assessment after all skills guidance has been carried out) by using the checklist provided in the guide. At the end of the semester students take a practical exam in the form of OSCE for all competencies in 3 blocks. Distribution of Clinical Skills scores in the previous semester still did not reach the desired maximum results.
\end{abstract}




\section{Purpose and Learning Objectives}

At the end of the module the student is able to carry out emergency management of midwifery.

\section{Block Contribution or Learning Outcomes in The Study Program Curriculum.}

Includes achievement areas for competencies 1-7 namely: legal ethics and patient safety, effective communication, personal development and professionalism, scientific foundation for midwifery practice, clinical skills in midwifery practice, health promotion and counseling and management and leadership.

\section{Research Methods and Development of Learning Methods}

The research sample was all students of the Midwifery Faculty of Medicine, Andalas University Year 2016. This research combines qualitative and quantitative research.[1]

\section{Development of Learning Methods}

Learning method that will be developed is to bring a expert team at the beginning of learning Clinical Skills in block 6B, students and all clinical instructors in each guidance group are expected to have the same mindset towards the desired learning outcomes, other than that by bringing a expert team at the beginning of this Clinical Skills learning, clinical instructors are expected to have the same skills / competencies for all guidance groups, so that all students are also expected to have the same ability to receive knowledge transfer from their respective clinical instructors even if they are in a group different guidance.

\section{Planning}

The application of this learning method is planned to bring in a expert team at the beginning of the Midwifery Emergency Skills Clinical Learning meeting in block 6B. All students and the team of supervisors who then act as clinical instructors are expected to have the same mindset in understanding the achievement of competencies that will be mastered by students, so that all students are expected to gain the same understanding and ability in mastering the material in Midwifery Emergency Clinical Skills, despite being in different guidance groups.

\section{Implementation}

At the implementation stage, learning method in Block 6B Midwifery Emergency Clinical Skills is expected to be adjusted to the existing planning, presenting a team of experts at the beginning of the Midwifery Emergency Clinical Skills learning.

\section{Results and Discussion}

Table 1. Comparison of Student Practice Test Values in Midwifery Emergency Clinical Skills Subjects

\begin{tabular}{|c|c|c|c|c|c|}
\hline \multirow{2}{*}{ Score Range } & \multicolumn{2}{|c|}{ Year 2015} & \multicolumn{2}{|c|}{ Year 2016} & \multirow{2}{*}{$\rho$ value } \\
\hline & $\mathrm{f}$ & $\%$ & $\mathrm{f}$ & $\%$ & \\
\hline $96-100$ & 1 & 2.4 & 21 & 51.2 & \multirow{4}{*}{0.001} \\
\hline $91-95$ & 9 & 12.9 & 19 & 46.3 & \\
\hline $86-90$ & 11 & 26.8 & 1 & 2.4 & \\
\hline $81-85$ & 20 & 48.8 & 0 & 0 & \\
\hline
\end{tabular}


From table 1 it can be seen that the results of student learning in the Midwifery Emergency Clinical Skills conducted at students of year 2015 carried out without bringing in an expert team at the beginning of the guidance found that $48.8 \%$ of students had grades in the range $81-85$, and only $2.4 \%$ of students have grades in the range 96-100. After developing the learning methods in the Emergency Clinical Skills students in year 2016 by bringing in the expert team at the beginning of the guidance by involving the Clinical Skills instructor (instructor) and the students found that $51.2 \%$ of students had grades in the range 96-100, and there are $2.4 \%$ of students who have grades in the range 86-90.

It can be seen the tendency of increasing student learning outcomes in learning Midwifery Emergency Clinical Skills. After doing statistical tests, it was found that $\rho$ value $=$ 0.001, meaning that there was a mean difference between student learning outcomes in Midwifery Emergency Clinical Skills for 2015 and 2016 class students. In addition to the data obtained and processed quantitatively, qualitatively data / information has also been obtained from students who provide an overview of student responses to the actions of developing learning methods undertaken.

Table 2 Comparison of student responses from the method of development carried out

\begin{tabular}{|c|c|}
\hline Without Development Method & With Development Method \\
\hline $\begin{array}{l}\text { - Students get clinical skills learning only in the } \\
\text { group }\end{array}$ & $\begin{array}{l}\text { - Students can get clinical skills learning from } \\
\text { expert teams (experts) and continue to the } \\
\text { guidance group. }\end{array}$ \\
\hline $\begin{array}{l}\text { - Students get competencies according to the } \\
\text { competencies of the supervisors in each group. }\end{array}$ & $\begin{array}{l}\text { - Students gain competency in accordance with the } \\
\text { competencies displayed by the expert team at the } \\
\text { beginning of learning and continued by the } \\
\text { supervisor (instructor) in the guidance of each } \\
\text { group. }\end{array}$ \\
\hline $\begin{array}{l}\text { - Often found differences in perceptions between } \\
\text { students in different guidance groups in } \\
\text { working on a skill. }\end{array}$ & $\begin{array}{l}\text { - There is a common perception among students } \\
\text { even in different guidance groups in working on } \\
\text { a skill. }\end{array}$ \\
\hline
\end{tabular}

From the table 2, it can be seen that the method of development carried out in the Midwifery Emergency Clinical Skills can have positive impact on students, students have the same perceptions in obtaining information related to the competency of the skills to be carried out, even though students have divided and are in the guidance of small groups with different supervisors (instructors).

The method of development carried out by bringing in a expert team of at the beginning of learning Clinical Skills can equip students with theories and competencies that will be mastered and re-trained in the guidance group, so that this can improve students' understanding and ability to receive learning related to mastering competency (practice), this can be seen from the tendency of the acquisition of student scores on the practical exam conducted.

Every person has a tendency to see the same thing in different ways so that sometimes differences in perception occur. Someone's perception is influenced by internal factors 
(feelings, attitudes and personality of individuals, prejudices, desires or hopes, attention (focus), learning processes, physical conditions, psychiatric disorders, values and needs as well as interests, and motivation) and external factors (family background information obtained, knowledge and needs around, intensity, size, resistance, repetition of motion, new and familiar things or the alienation of an object). [2]

There are various factors that influence the implementation of clinical skills for students in achieving their competence. Obstacles in the learning process and the achievement of clinical skills, among others, the skills of the available lab skills are still limited, the lack of time allocation and problems with the instructor. [3]

The implementation of Skillab in Undergraduate Midwifery Program is facilitated by several instructors who are very competent in their fields. But due to various factors, so it is also possible to experience different perceptions in the same team of a competency that will be conveyed to students. The response as a result of perception can be received by individuals in various ways depending on the attention of the individual concerned. Feelings, thinking abilities, experiences owned by individuals are not the same, so in perceiving something stimulus, the results of perception may be different between one individual with another individual. Everyone has a tendency to see the same object in different ways. These differences can be influenced by many factors, including knowledge, experience and perspective. [4] Therefore, the Equalization of Perception is the initial process of building an understanding between fellow skillab instructors. A hadith says that everything must be left to the experts, just as the implementation of the skills lab activities must be led by a trainer who is an expert in that field.

In Wardani's research, 2019, it was stated that supporting lecturers in skillab learning must be given the opportunity to actively increase their knowledge such as attending training, internships, etc. so that the knowledge given to students is the latest applied knowledge. [5]

In training the clinical skills of students in achieving competence, many factors influence the achievement of these competencies, in addition to the training methods used, the available lab skills facilities, the characteristics of student learning, certainly not apart from the role and skills / expertise of the kilinic skills instructor at the time of the skill the lab. An instructor has an important role in learning the lab skills. An instructor's performance in teaching lab skills greatly influences the quality of the competencies achieved by a student.

\section{Conclusions}

a. An increase in the achievement of student learning outcomes by applying the development of learning methods carried out.

b. Development of learning methods can better meet the learning achievements of graduates by uniforming the abilities / competencies possessed by clinical instructors and students

\section{References}

[1] Prastowo, 2010. Mengetahui Teknik-teknik Koleksi Data Penilaian Kualitatif. Yogyakarta : Diva Press.

[2] Sugihartono, dkk. 2007. PsikologiPendidikan.Yogyakarta: UNY Press.

[3] Hardisman., Yulistini. (2013). Pandangan Mahasiswa Terhadap Hambatan pada Pelaksanaan Skills Lab di Fakultas Kedokteran Universitas Andalas. 
[4] Wardani, Ika Kusuma, dkk. Perencanaan Pembelajaran Skills Lab Keperawatan di Sekolah Tinggi Ilmu Kesehatan PKU Muhammadiyah Surakarta , PROFESI (Profesional Islam): Media Publikasi Penelitian . 2019; Volume 16; No 2. Website: ejournal.stikespku.ac.id

[5] Waidi, 2006. Pemahaman dan teori persepsi. RemajaKarya, Bandung 